\title{
THE IMPORTANCE OF GROWING MAIZE AND CORN AS ROTATIONAL CROPS
}

\author{
Sayimbetov Alisher ${ }^{1}$, Shamambetov Qoblan Qarjawbay uli ${ }^{2}$ \\ ${ }^{1}$ Doctor of Philosophy (PhD) in Agricultural Sciences, Docent of the Department Farming, Selection \\ and Seed Breeding of Agricultural Crops, Nukus branch of Tashkent State Agrarian University, \\ Nukus, Karakalpakstan, Uzbekistan \\ ${ }^{2}$ Master's Student, Nukus Branch of Tashkent State Agrarian University, Nukus, Karakalpakstan, \\ Uzbekistan
}

Article DOI: https://doi.org/10.36713/epra8628 DOI No: $10.36713 /$ epra8628

\begin{abstract}
ANNOTATION
In the case of saline soils of the north zone of Karakalpakstan, it is important to study the influence of growing maize and corn as rotational crops after winter wheat on the continuation of the vegetation period and cultivating the soil. Under these conditions, after the winter wheat, when the soil is cultivated in good quality in the production of maize and corn as rotational crops, maize and corn grow well and there is a large amount of fodder from green mass for livestock.
\end{abstract}

KEYWORDS: crop rotation, land cultivation, plowing, subsoiling, fodder, maize, corn, green mass.

\section{INTRODUCTION}

In agriculture, especially, in developing fodder production, it is important and necessary to complete tasks on fully providing animal husbandry farms with qualitative fodder by developing maize and corn production as rotational crops for fodder.

It will increase the production of animal husbandry products in Uzbekistan and is a necessary task to improve its quality. In order to fulfill this task, it is necessary, first of all, to strengthen the fodder base of the farm.

In recent years, 4 districts of Karakalpakstan specialized in animal husbandry, with the organization of multi-sectoral farms, agricultural clusters and agro-farms, a great attention is being paid to strengthen the fodder base of the animal husbandry. In Karakalpakstan, winter wheat is planted to most fields, and the vacated fields need to be re-planted, which makes it more efficient to use the climatic and soil conditions of the republic.

F.Boboev and others [2] noted that if the hybrid maize "Uzbekistan - 300 AMV" is planted and harvested in the first decade of July, the grain will ripen in 90-96 days before the days begin to cool and rain. It is noted that if the germination is delayed for 2-3 decades of July, it is possible to obtain nutritious silage.

B.Abdolniyozov [1] in his experiments studied the hybrids of maize "Moldavia", "Nart" and "Uzbekistan-306 AMV" and "Vatan", planted as a rotational crop after winter wheat, and obtained the following results: $37.0 \mathrm{t} / \mathrm{ha}$ of grain from the hybrid "Moldavia" and $97.0 \mathrm{c} / \mathrm{ha}$ of stalks, 33 and $102 \mathrm{c} / \mathrm{ha}$ of "Nart" hybrid, $34.0 \mathrm{c} / \mathrm{ha}$ of grain and $123 \mathrm{c} / \mathrm{ha}$ of stems from "Vatan" hybrids, i.e. total nutrient unit per hectare (grain + stalks) respectively 66.4; 67.9 and $66.8 \mathrm{t} / \mathrm{ha}, 61.5 \mathrm{t} / \mathrm{ha}$ of grain and $131.8 \mathrm{t} / \mathrm{ha}$ of stalks were obtained from the hybrid "Uzbekistan306 AMV". During the application period, the crop was irrigated 3-4 times at a rate of $600-700 \mathrm{~m}^{3} / \mathrm{ha}$.

Chinese scientists Manxiang Huang, Tao Liang, Lingqing Wang, Chenghu Zhou [5] studied the effect on soil agrophysics when planting wheat in the main crop maize as a rotational crop for a long time without cultivating the land. The results of the study showed that in the application of nitrogen fertilizer in addition to unprocessed wheat straw and in the application of manure and nitrogen fertilizer in unprocessed wheat straw, the weight of the soil was slightly reduced compared to the control option and 


\section{EPRA International Journal of Research and Development (IJRD)}

soil water-resistant aggregates $(>2 \mathrm{~mm})$ and water permeability increased.

According to D. Edenbaev, K. Azizov [4], the "Uzbekskoe 18" type, which is regionalized in Shimbay district, yielded 560-620 c/ha of green mass when the grains were harvested during the milk ripening phase for 3 years (2012-2014). "Uzbekskoe 18 " (late ripening), “Oranjevoe 160" (medium ripening) and "Karabas" (fast ripening) varieties of corn were planted on the field of "Azamat" farm of Khojeli region which has good water permeability, and the amount of green mass was 746.8; 472.6 and $312.6 \mathrm{c} / \mathrm{ha}$.

\section{METHODS OF CONDUCTING THE EXPERIMENT}

Field experiments were carried out in the conditions of saline soil in experimenting fields of KSSRI during 2020-2021 and according to the following variants. Maize was planted in 1-3 variants, in this, 1st variant is controlling $(10-12 \mathrm{~cm}$ subsoiling, plowing); in the 2nd variant $15-18 \mathrm{~cm}$ subsoiling, plowing; in the 3rd variant $20-25 \mathrm{~cm}$ plowing. Maize was planted in variants 4-6, including $1 \mathrm{st}$ variant is controlling $(10-12 \mathrm{~cm}$ subsoiling, plowing); in the 2nd variant $15-18 \mathrm{~cm}$ subsoiling, plowing; in the 3rd variant $20-25 \mathrm{~cm}$ plowing.

The research is currently being conducted on the basis of methodological manual of the UzPITI "Methods of conducting field experiments" (Tashkent 2007).

\section{RESULTS OF THE RESEARCH}

In the case of saline soils of the north zone of Karakalpakstan, it is important to study the influence of growing maize and corn as rotational crops after winter wheat on the continuation of the vegetation period, biometric indicators, development, yield of green mass fodder and cultivating the soil. Under these conditions, after the winter wheat, when the soil is cultivated in good quality in the production of maize and corn as rotational crops, maize and corn grow well and there is a large amount of fodder from green mass for livestock.

In practice, the influence of growing maize and corn as rotational crops after winter wheat was studied and research is being continued. At the same time, after the winter wheat was harvested, the experimental options were arranged.

The study identified differences in variants compared to observations on seedling thickness of rotational crops.

It was observed that the seedling thickness of maize and corn was slightly higher in the variant, when 20-25 cm subsoiling, plowing was used, in comparison with other variants.
After harvesting the yield of winter wheat, it is necessary to apply various tillage to the soil, i.e. subsoiling and plowing in different depth in order to have a positive effect on the agrophysical properties of the soil. In this case, comparing to the variant, when 10-12 cm subsoiling, plowing were carried out, in the variant, when $15-18 \mathrm{~cm}$ subsoiling and $20-25$ $\mathrm{cm}$ plowing were carried out, both plants have more growth and development.

In the experiments, depending on the method of soil preparation, the growth of forage crops was different, and after harvesting the yield of winter wheat, in variant, when $10-12 \mathrm{~cm}$ subsoiling and plowing were conducted and mazie and corn were planted as rotational crops, their height was 140-150 cm, number of leaves 9-20, in variant, when $15-18 \mathrm{~cm}$ subsoiling and plowing were carried out, $145-160 \mathrm{~cm}$, number of leaves 10-11, and in variant, when $20-25 \mathrm{~cm}$ subsoiling and plowing were carried out, 150-180 cm, number of leaves 11-12.

It was defined that in the fields where maize and corn were planted as rotational crops, the growth and development of the plant was lower in variant, when $15-18 \mathrm{~cm}$ subsoiling and plowing were carried out, compared to the variant, when subsoiling and plowing were carried out in $20-25 \mathrm{~cm}$ depth, and in variant, when $10-12 \mathrm{~cm}$ subsoiling and plowing were carried out and rotational crops were planted, it was high.

In the variant, when $15-18 \mathrm{~cm}$ subsoiling and plowing were carried out, there was good conditions for the growth and development of the plant, and receiving high yield. When 15-18 cm subsoiling and plowing were carried out and rotational crops were planted, comparing to other variants materials of fuel were saved, and it is economically efficient.

\section{CONCLUSION}

In the Republic of Karakalpakstan, the use of maize and corn as fodder crops in the sustainable use of arable land has significant importance in increasing the fodder base of the farm.

\section{REFERENCES}

1. Abdolniyozov B. Growing rotational forage crops. // Journal of Agriculture of Uzbekistan. Tashkent, 2002, № 2. P.43-44.

2. Boboev F. and others. New hybrid "Uzbekistan 300 MV" of maize planted in Angiz. // Journal of Agriculture of Uzbekistan. Tashkent, 2015, № 5. P. 39 .

3. Methods of conducting field experiments. Tashkent, UzPITI, 2007. P. 1-146.

4. Edenbaev D., Azizov K. Sorghum - plant of many opportunities. Journal "Agroilm". Tashkent, 2020, №1 (64). P. 30-31. 
5. Manxiang Huang, Tao Liang, Lingqing Wang, Chenghu Zhou. Effects of no-tillage systems on soil physical properties and carbon sequestration under long-term wheat - maize double cropping system. CATENA. Volume 128, May 2015, P. 195-202. 